\title{
Shoemaker vs. Sutherland: A Criminological Debate
}

T. Lamont Baker

$\mathrm{I}$ n 1939, a sociologist by the name of Edwin H. Sutherland presented his differential association theory in a text titled Principles of Criminology. Eight years later, in 1947, Sutherland - a towering figure in the sociological study of crime - presented his final version of this theory in a revised edition Principles of Criminology. This version has appeared in most criminology textbooks published in the last half century.

In short (and by "in short", I aim to acknowledge the risks associated with oversimplifying such a complex postulate), the essence of differential association theory maintains that delinquency is the product of being exposed to more lawless temperaments and law-breaking attitudes than law-abiding ones. Sutherland divided this theory into nine propositions, one of which puts forward the notion that the degree of delinquency that results from associating with delinquents depends upon four primary factors: frequency (how often one associates with delinquents), duration (how long each association lasts), priority (how early in life these associations occur), and intensity (how much importance one places on these associations).

In Theories of Delinquency: An Examination of Delinquent Behavior (2000), Donald J. Shoemaker attempted to delegitimize this proposition by asserting that police officers have frequent, prolonged, high-priority and intense contact with criminals, but do not usually adopt these criminals' attitudes. Shoemaker's implied intention was to criticize and discredit Sutherland's position, but not only is his criticism tremendously flawed, it actually had an effect that is opposite of his intended one. His narrow, pancultural, and haughty perspective of police activities is the reason why this specific critique actually supports Sutherland's theory instead of disproving it.

To begin with, studies and surveys have shown that most police officers pursue a career in law enforcement because they view themselves as diametrically opposed to and detached from crime commission and because they have a desire to combat illegality. They believe that crime needs to be eradicated and that those who commit crimes must be stopped. Their self-identify is fundamentally contrary to "criminal" from the onset, and they believe that the crimes that criminals commit, and that the actions that criminals have allegedly monopolized, are wrong. These officers want to be the ones to fight against them. Simply put, cops tend to define themselves as both non- and anti-criminal. Shoemaker would likely agree with these 
findings and rejoice when reminded that most policemen (and policewomen) convince themselves that they are averse to criminal practices and attitudes.

If actions, however, are a manifestation of one's attitudes, then this aversion is a sham. Police, more often than not, initiate and carry-out the very activities that they claim to be opposed to. Shoemaker's incognizance of, and inexperience with, the plights and vistas of people on the other side of the legal divide are the reason that he is unaware of this reality.

In reading Shoemaker's work, I am not only reminded of his lack of awareness but also of his arrogant assumption that the only valid interpretation of law enforcement practices is that of law enforcement personnel and their blind sympathizers. Another interpretation - which is just as substantive and worthy of equal consideration - needs to be acknowledged: that of the criminological objectives. The following interpretation of my past experience, both confirms and endorses this interpretation's worthiness in a manner that effectively challenges Shoemaker's aforementioned take on the differential association theory. ${ }^{1}$

As a teenager, I endured a variety of experiences that helped form my perception of "police criminality", a perception that Shoemaker's work fails to account. These experiences, and my analysis of them, undoubtedly support the differential association theory and directly counter Shoemaker's argument.

For example, I have stared down the barrels of numerous officers' service weapons (brandishing a firearm) after being pulled over on "routine" traffic stops. In these situations, I did as these officers told me, which was to get out of the car and move slowly or be shot (communicating threats). I have been directed, at gunpoint, to walk a certain distance to a specific location (second degree kidnapping) and empty my pockets (armed robbery). I have had officers enter my home, go into my bedroom (breaking and entering) and confiscate some of my legally possessed property without warrant or permission (burglary). I can also recall an incident involving multiple policemen entering my house with their guns drawn without a warrant and barking unnecessary orders (home invasion). I have been slammed to the ground, choked and kicked by police officers (aggravated assault). I have been placed in handcuffs, taken to jail and held in a cell for hours only to be released without being charged with anything (first degree kidnapping). I have been pulled over and forced to stand back and watch as officers literally ripped up the carpet in my vehicle (destruction of private property). I have had them actually dare me to take a weapon that they were trying to shove 
into my hand (contributing to the delinquency of a minor) so that they could have a reason to use brutal force to take it away from me. They have come onto my parents' property without just cause or permission (trespassing), placed me in cuffs and accused me of things that I did not do (defamation of character). These policemen have sprayed me with mace (simple assault) and commanded snarling police dogs to attack me (attempted assault with a deadly weapon), but luckily I was able to lock myself in a room or in a car to prevent a sure mauling. I have seen the police do things that, if done by a civilian, would result in prison time. But more importantly, none of these incidents were the result of my misbehaviour.

At this point, if you are as myopic as Shoemaker, you may be drumming up accusations to direct my way. You may be revealing your myopia, as well as your inexperience, by asserting that I had to have been doing something wrong in order to receive so much attention from the police. You may be right if you consider walking down a sidewalk or attending a party "wrong". You also may be right if you deem going to a basketball court with friends, being in the area where a spontaneous fistfight erupts between strangers or wearing urban athletic attire as grounds for harassment by law enforcement officers.

Such accusations also inform me that your parents never had the Talk with you as a youth, the Talk that all decent fathers of young black men have with their sons around their sixteenth birthday: "If you're stopped by a cop, do what he says, even if he's harassing you, even if you didn't do anything wrong. Let him arrest you, memorize his badge number and call me as soon as you get to the precinct. Keep your hands where he can see them. Do not reach for your wallet. Do not grab your phone. Do not raise your voice. Do not talk back. If he verbally threatens you, don't talk at all. If you see his hands go to his gun, don't move at all. If he grabs you, don't fight back. Do you understand me?"

And despite your detachment from the side of law enforcement that makes these sorts of "talks" necessary, there is still one fact that confirms the groundlessness of my aforementioned past encounters with police: none of them led to or resulted in an official arrest or criminal charges of any kind. I was not a criminal when these events transpired, although I did become one eventually. These incidents all occurred while I was in high school, while my record was clean, my face was full of acne, my curfew was 9pm, and while I still thought that old people smelled funny, 
and that armpit farts were hilarious. The officers not only treated me like a criminal, they acted like criminals themselves - all before my behaviour could justify criminal deeds. ${ }^{2}$

The very actions that aspiring police officers claim to be averse to are the very actions that cops used to terrorize me, and countless others, throughout my teenage years prior to my brief yet willing embracement of criminality, which led to my confinement at 19 years old. The argument can even be made that such terror was a contributing factor to my eventual loss of reverence for the institutions of law enforcement and lawful citizenship - not the sole factor, but a contributing factor nonetheless. However, my point here is not digression for digression's sake, nor is it to focus solely on criminogenic policing mechanisms or to assign total blame for my past misconduct directly on police officers. That would not only be a misappropriation of blame, but it would also discredit my counterargument against Shoemaker's rebuttal to the differential association theory.

My point here is to highlight the fact that, from behind badges, the police regularly commit the same (mis)behaviours that regular people usually get incarcerated for. These are the same (mis)behaviours that police officers claim to be opposed to, and that Donald Shoemaker has yet to factor into his theorization. Shoemaker's declaration that police do not commit criminal actions or adopt criminal attitudes despite frequent association with "criminals" is clearly counterfactual and the experiences noted above verify this.

A more accurate position would recognize that police officers do not commit criminal actions or adopt criminal attitudes until they complete training and begin to frequently associate with criminals. The fact that police are not criminal until after said training and association supports the first two factors of Sutherland's position - frequency and duration. The fact that said training and association occur at the onset of one's "cop life" (i.e. policing career) and serve as an officer's initiation into "officer hood" supports the third factor of Sutherland's proposition - priority. And lastly, considering that the focal point of cop life is opposing and arresting those identified as "criminals", I think it is safe to say that law enforcement personnel place tremendous importance on engaging those with criminal dispositions. This is confirmation of the last factor of the proposition that is pertinent to this essay - intensity. In Theories of Delinquency, Shoemaker rightly notes these truths before making his inaccurate assertion that these facts do not result in police criminality, when in fact they do. 
It is apparent that police adopt criminal attitudes and readily display criminal behaviours on a regular basis. Yet these attitudes and behaviours are not deemed criminal when their perpetrators are adorning badges. More specifically, Shoemaker does not categorize police officers' criminal attitudes and behaviours as criminal simply because of their shiny shields. This oversight discredits his position. The categorization of someone's disposition should not depend upon their career. Pointing a firearm at a lawabiding minor remains the same act whether executed by a policeman, the pope or a snot-nosed teenager.

Of course, the source of someone's temperament, or the reason that a person experiences a particular sentiment or behaves in a certain way can sometimes be traced to his or her career, but the actual diagnosis of behaviour itself should be made without reference to his or her chosen profession in this context. More simply put, a criminal attitude, which manifests through criminal behaviours, should not be overlooked, denied or misrepresented simply because it is possessed by someone who is above the law. Nor should the theorizations of a respected academic be tainted by an inability to see beyond a paradigm that favours a particular group of people because of their career - in Shoemaker's case this "group" happens to be law enforcement officers.

Such tainting prevents Shoemaker from recognizing that officers develop criminal tendencies - which can almost be described as addictions - after extensive association with delinquents over time. It also hinders any efforts to develop organic interpretations of public behaviour, such as my own, rooted in solid empirical information, supporting, rather than refuting, Sutherland's differential association theory.

It is my hope that users of differential association theory grow to consider and accept the validity of such interpretations and vistas and to refrain from relying exclusively on the one(s) with which he has grown so comfortable with and can't seem to see beyond. Furthermore, as I outline in my book, A Convict's Perspective: Critiquing Penology and Inmate Rehabilitation (Baker, 2014), we must all work together to engage, challenge and hopefully refine the scopes of individuals who are as highly regarded as Shoemaker, so that counterproductive critiques can be avoided, criminal penchants can be prevented, and true progress can be made. 


\section{ENDNOTES}

1 One would be hard-pressed to locate someone who is both aware of frontline police activities through first-hand experiences, such as those referenced above, and who would refute my position. Quite the contrary. Most who have been arrested, labelled as a person of interest or suspected of committing a crime, will say that my position is a little "toned down" or diluted, and this is understandable. I grew up in a solid middle-class, two-parent household. I was enrolled in college at the time of my imprisonment. My pre-prison experiences with police were less virulent, less tumultuous and less inflaming than those of many of my fellow prisoners. So, in interpreting my experiences with officers of the law, I am speaking from the more moderate end of the spectrum, so to speak.

2 I would like to clearly state that, even if these events had followed rather than preceded my season of individual delinquency, it would still be absolutely ridiculous for police officers to use criminal acts to combat criminality. Such acts only fertilize criminality, they do not extinguish it.

\section{REFERENCES}

Baker, T. Lamont (2014) A Convict's Perspective: Critiquing Penology and Inmate Rehabilitation, U.S.: Createspace.

Shoemaker, Donald J. (2009) Theories of Delinquency: An Examination of Delinquent Behaviour, London: Oxford University Press.

Sutherland, Edwin Hardin and Donald Cressey (1992) Principles of Criminology (eleventh edition), Lanham (MD): AltaMira Press.

\section{ABOUT THE AUTHOR}

T. Lamont Baker is a prisoner at Lumberton Institution and can be reached by mail at the following address:

T. Lamont Baker \#0915700

Lumberton Institution

75 Legend Road

Lumberton, North Carolina 28358

USA 